\title{
Induksi Kalus dan Regenerasi Tiga Genotipe Tomat (Solanum lycopersicon L.) melalui Kultur Antera
}

\author{
Callus Induction and Regeneration of Three Tomato Genotypes \\ (Solanum lycopersicon L.) through Anther Culture \\ Ratna Ningsih ${ }^{1}$, Bambang S. Purwoko ${ }^{2 *}$, Muhamad Syukur ${ }^{2}$, dan Iswari S. Dewi ${ }^{3}$ \\ Diterima 31 Maret 2016/Disetujui 06 Juli 2016
}

\begin{abstract}
The aims of this research were to evaluate culture ability of 3 tomato genotypes through their androgenic response in callus induction and regeneration media. Completely randomized design with factorial arrangement and 5 replications were used. Treatments consisted of three genotypes (Tora, Ratna and hybrid variety Permata), six callus induction media in the first phase and three genotypes and two regeneration media. The result showed that hybrid variety Permata had the highest anther culture ability then other genotypes. Permata had the highest percentage of callus induction (27\%) followed by Tora (14\%) and Ratna (12\%). The highest percentage of callus induction was shown in DBMI $+5 \mathrm{mg} \mathrm{L}^{-1}$ Kinetin $+2 \mathrm{mg} \mathrm{L}^{-1} \mathrm{NAA}$ media (39.7\%) followed by DBMII $+1 \mathrm{mg} \mathrm{L}^{-1}$ Kinetin $+2 \mathrm{mg} \mathrm{L}^{-1} \mathrm{NAA}$ media (33.0\%). Both genotypes and media gave low percentage of shoot induction. The percentage of shoot induction in hybrid variety Permata was $4.2 \%$ while in Tora was $2.1 \%$ and Ratna was $0 \%$. The percentage of shoot induction in MS $+25 \mathrm{mg} \mathrm{L}^{-1}$ Zeatin was $2.8 \%$ while in $M S+1 \mathrm{mg} \mathrm{L}^{-1}$ Zeatin $+0.125 \mathrm{mg} \mathrm{L}^{-1}$ IAA was $1.4 \%$.
\end{abstract}

Keywords: androgenesis, auxin, cytokinine, in vitro, medium, tomato

\begin{abstract}
ABSTRAK
Penelitian ini bertujuan untuk mengetahui daya kultur antera tiga genotipe tomat melalui percobaan induksi pembentukan kalus dan regenerasi tunas. Percobaan dirancang menggunakan Rancangan Acak Lengkap faktorial dengan lima ulangan. Bahan tanam yang digunakan ialah tomat varietas Tora, Ratna dan varietas hibrida Permata. Media yang digunakan adalah 6 media induksi kalus dan 2 media regenerasi tunas. Hasil penelitian menunjukkan bahwa tomat varietas hibrida Permata memiliki daya kultur antera yang lebih baik dibandingkan genotipe lainnya. Permata memiliki persentase jumlah kalus $27 \%$ lebih tinggi dibandingkan Tora (14\%) dan Ratna (12\%). Media yang paling baik menginduksi kalus adalah media DBMI $+5 \mathrm{mg} \mathrm{L}^{-1}$ Kinetin $+2 \mathrm{mg} \mathrm{L}^{-1}$ NAA (39\%) dan DBMII $+1 \mathrm{mg} \mathrm{L}^{-1}$ Kinetin $+2 \mathrm{mg} \mathrm{L}^{-1} \mathrm{NAA}$ (33\%). Baik genotipe maupun media yang digunakan menghasilkan jumlah tunas yang rendah. Persentase induksi tunas varietas hibrida Permata $4.2 \%$ lebih tinggi dibandingkan Tora $(2.1 \%)$ dan Ratna $(0 \%)$. Persentase induksi tunas media MS + $0.25 \mathrm{mg} \mathrm{L}^{-1}$ Zeatin $(2.8 \%)$ lebih tinggi dibandingkan media $\mathrm{MS}+1 \mathrm{mg} \mathrm{L}^{-1}$ Zeatin + $0.125 \mathrm{mg} \mathrm{L}^{-1}$ IAA $(1.4 \%)$.
\end{abstract}

Kata kunci: androgenesis, auksin, in vitro, media, sitokinin, tomat

\section{PENDAHULUAN}

Tomat menempati peringkat ke 11 dalam 50 besar komoditas pertanian dunia dan menempati peringkat ke 8 di Asia (FAO,
2015). Tomat juga termasuk dalam kategori buah favorit dunia dengan produksi mencapai 60 juta ton tahun ${ }^{-1}$ melebihi produksi pisang, jeruk dan apel. Di Indonesia, tomat menempati peringkat ke lima dalam komoditas sayuran

${ }^{1}$ Program Studi Pemuliaan dan Bioteknologi Tanaman, Fakultas Pertanian, Sekolah Pascasarjana, Institut Pertanian Bogor (Bogor Agricultural University), Jl. Meranti, Kampus IPB Dramaga, Bogor 16680, Indonesia

${ }^{2}$ Departemen Agronomi dan Hortikultura, Fakultas Pertanian, Institut Pertanian Bogor (Bogor Agricultural University) J1. Meranti Kampus Darmaga, Bogor 16680 Indonesia. Telp/ Faks. 62-251-8629353.

${ }^{3}$ Balai Besar Penelitian dan Pengembangan Bioteknologi dan Sumberdaya Genetika Pertanian, Jl. Tentara Pelajar No. 3 A Bogor, Indonesia email: bspurwoko@ipb.ac.id (*penulis korespondensi) 
setelah kubis, kentang, cabai besar dan bawang merah (Badan Pusat Statistik, 2013 dan Direktorat Jenderal Hortikultura, 2011). Produksi tomat nasional masih mengalami fluktuasi sehingga diperlukan upaya untuk meningkatkan dan menstabilkan produksi. Salah satu upaya yang dapat dilakukan adalah melalui penggunaan varietas unggul.

Varietas unggul dapat diperoleh melalui persilangan tetua galur murni dengan karakter unggul yang diinginkan, sehingga hibrida yang dihasilkan memberikan keuntungan secara komersial (Syukur et al., 2012). Umumnya galur murni diperoleh melalui persilangan yang diikuti oleh serangkaian seleksi yang membutuhkan waktu lama, sehingga diperlukan metode yang dapat mempercepat perolehan galur murni. Kultur antera dapat digunakan untuk mempersingkat siklus tersebut karena tanaman dihaploid yang dihasilkan dapat diperoleh pada generasi pertama. Melalui penggunaan sistem haploid waktu yang diperlukan untuk memperoleh galur murni dapat dipercepat menjadi satu sampai dua generasi saja (Dewi dan Purwoko, 2011).

Antera dan mikrospora memegang peranan yang penting dalam upaya peningkatan produksi (Harliani et al., 2014; Sudarmono dan Destri, 2013; Kartikaningrum et al., 2012). Salah satu penggunaan antera dalam upaya peningkatan produksi di bidang pemuliaan tanaman adalah melalui kultur antera untuk mempercepat perolehan galur murni. Penggunaan kultur antera dalam program pemuliaan tomat saat ini belum mendapat perhatian karena terbatasnya informasi mengenai kultur antera tomat di Indonesia. Berbagai hasil penelitian kultur antera tomat yang dilaporkan dari tahun 1972 hingga 2010 masih terkait respon genotipe terhadap kondisi kultur dan kajian mengenai faktor-faktor pembatas keberhasilannya (Motallebi-Azar, 2010; Gresshoff dan Doy, 1972; Sharp et al., 1972). Belum ada metode yang stabil hingga saat ini disebabkan karena besarnya pengaruh genotipe yang digunakan. Keberhasilan kultur antera tomat juga dipengaruhi oleh komposisi media kultur, fase perkembangan mikrospora (Seguì-Simarro dan Nuez, 2005), kondisi fisiologi tanaman donor, pra perlakuan sebelum kultur (Motallebi-Azar dan Panahandeh, 2010), dan kondisi lingkungan kultur. Penelitian ini bertujuan mengetahui respon tiga genotipe tomat dalam kultur antera melalui percobaan induksi kalus dan regenerasi tunas.

\section{BAHAN DAN METODE}

Penelitian dilaksanakan di laboratorium Biologi Sel dan Jaringan, Balai Besar Penelitian dan Pengembangan Bioteknologi dan Sumber Daya genetik Pertanian (BB Biogen), dan Rumah Kaca Cikeumeh, Cimanggu, Bogor dari bulan April 2015 sampai April 2016.

Bahan tanaman yang digunakan adalah genotipe Tora, Ratna (koleksi Laboratorium Pemuliaan Tanaman, Departemen Agronomi dan Hortikultura, IPB) dan genotipe hibrida Permata yang diperoleh dari toko pertanian. Media tanam yang digunakan terdiri atas enam media induksi kalus dan 2 media induksi tunas. Media induksi kalus yang digunakan yaitu M1: DBMI $+5 \mathrm{mg} \mathrm{L}^{-1}$ kinetin $+2 \mathrm{mg} \mathrm{L}^{-1}$ NAA (Gresshoff dan Doy, 1972), M2: DBMII $+1 \mathrm{mg} \mathrm{L}^{-1}$ kinetin $+2 \mathrm{mg} \mathrm{L}^{-1}$ NAA (Gresshoff dan Doy, 1972), M3: DBMIII + $0.01 \mathrm{mg} \mathrm{L}^{-1}$ kinetin $+5 \mathrm{mg} \mathrm{L}^{-1} \mathrm{NAA}$ (Gresshoff dan Doy, 1972), M4: MS + $1 \mathrm{mg} \mathrm{L}^{-1} 2 \mathrm{ip}+2 \mathrm{mg} \mathrm{L}^{-1} \mathrm{IAA}$ (Motallebi-Azar, 2010), M5: MS + $0.02 \mathrm{mg} \mathrm{L}^{-1}$ 2.4-D $+2 \mathrm{mg} \mathrm{L}^{-1}$ kinetin (Motallebi-Azar, 2010), dan M6: MS + $0.25 \mathrm{mg} \mathrm{L}^{-1}$ zeatin + 0.5 mg L ${ }^{-1}$ IAA (Zagorska et al., 1998). Media induksi tunas yang digunakan yaitu R1: MS + $1 \mathrm{mg} \mathrm{L} \mathrm{L}^{-1}$ zeatin $+0.125 \mathrm{mg} \mathrm{L} \mathrm{L}^{-1}$ IAA (Motallebi-Azar, 2010) dan R2: MS + $0.25 \mathrm{mg}$ $\mathrm{L}^{-1}$ zeatin (Seguì-Simarro dan Nuez, 2007, 2005).

\section{Induksi Pembentukan Kalus pada Enam Media Kultur}

Percobaan 1 dirancang menggunakan Rancangan Acak Lengkap dua faktor. Faktor pertama yaitu genotipe yang terdiri atas 3 genotipe (Tora, Ratna, dan Permata). Faktor kedua yaitu media yang terdiri atas 6 media (M1, M2, M3, M4, M5, dan M6), sehingga terdapat 18 kombinasi perlakuan. Tiap kombinasi perlakuan diulang sebanyak 5 kali, sehingga terdapat 90 satuan percobaan. Satu satuan percobaan adalah satu petri yang berisi 20 antera.

Kuncup yang berukuran 3 hingga $7 \mathrm{~mm}$ diambil pada pagi hari selama 25 hingga 30 
hari masa berbunga (Motallebi-Azar, 2010). Kuncup yang diambil diberi pra perlakuan berupa penyimpanan pada suhu $5^{0} \mathrm{C}$ selama 48 jam dalam kondisi gelap. Kuncup yang telah diberi pra perlakuan selanjutnya disterilisasi di dalam Laminar Air Flow Cabinet. Kuncup direndam dalam larutan Clorox $20 \%$ selama 10 menit, kemudian dibilas dengan air steril sebanyak 3 kali dan ditiriskan pada kertas saring steril. Antera kemudian dipisahkan dari kuncup bunga menggunakan pinset lalu diinokulasi pada petri yang berisi $10 \mathrm{ml}$ media induksi kalus. Tiap petri berisi 20 antera yang berasal dari 4 kuncup bunga. Petri yang telah berisi antera diinkubasi gelap selama 6 minggu pada suhu $26 \pm 2{ }^{0} \mathrm{C}$ kemudian dipindahkan pada kondisi penyinaran 16/8 jam dengan suhu yang sama. Pengamatan dilakukan terhadap lamanya inisiasi kalus dalam Hari Setelah Tanam (HST) dan jumlah kalus yang terbentuk. Data primer yang diperoleh digunakan untuk menghitung persentase kalus terhadap jumlah antera. Data dianalisis menggunakan analisis ragam dan dilanjutkan dengan uji DMRT pada taraf $\alpha=5 \%$ bila terdapat pengaruh pada perlakuan.

Persentase (\%) kalus terhadap jumlah antera $=\frac{\text { Jumlah kalus }}{\text { Jumlah total antera }} \times 100 \%$.

\section{Induksi Pembentukan Tunas pada Dua Media Regenerasi}

Percobaan 2 dirancang menggunakan Rancangan Acak Lengkap dua faktor. Faktor pertama adalah kalus dari 3 genotipe (Tora, Ratna dan Permata) yang berasal dari percobaan 1. Faktor kedua adalah media induksi tunas yang terdiri atas 2 media (R1 dan R2), sehingga terdapat 6 kombinasi perlakuan. Tiap kombinasi perlakuan diulang sebanyak 8 kali sehingga terdapat 48 satuan percobaan. Satu satuan percobaan adalah satu botol yang berisi 3 kalus.

Kalus dari tiap genotipe yang telah berukuran $2 \mathrm{~mm}$ hingga lebih dipindahkan pada media induksi tunas $\mathrm{R} 1$ dan $\mathrm{R} 2$ dan diinkubasi pada suhu $26 \pm 2{ }^{0} \mathrm{C}$ dengan penyinaran 16/8 jam. Pengamatan dilakukan terhadap diameter kalus pada minggu ke-4 dan ke-6, lamanya inisiasi tunas dalam Hari setelah Tanam (HST) dan jumlah tunas. Data primer digunakan untuk menghitung persentase jumlah tunas terhadap jumlah kalus dan pertambahan diameter kalus. Data dianalisis menggunakan analisis ragam dan dilanjutkan dengan uji DMRT pada taraf $\alpha=5 \%$ bila terdapat pengaruh pada perlakuan.

Persentase (\%) jumlah tunas terhadap

jumlah kalus $=\frac{\text { jumlah tunas }}{\text { Jumlah total kalus }} \times 100 \%$

Pertambahan diameter kalus $=$ diameter kalus minggu ke-6 diameter kalus minggu ke-4.

\section{HASIL DAN PEMBAHASAN}

\section{Induksi Pembentukan Kalus}

Pembentukan kalus merupakan salah satu tahapan dalam pembentukan tanaman pada kultur antera tomat (Motallebi-Azar, 2010; Segui-Simarro dan Nuez, 2005) yang juga ditemukan pada berbagai kultur antera tanaman seperti cabai (Muswita, 2003), dan padi (Safitri et al., 2010; Dewi et al., 2009; 2007; Dewi dan Purwoko, 2001).

\section{Lamanya Inisiasi Kalus}

Antera ditanam pada petri yang berisi $10 \mathrm{ml}$ media, kemudian diinkubasi gelap selama 6 minggu untuk menginduksi pembentukan kalus (Gambar 1a). Kalus yang terbentuk pada ketiga genotipe dan media induksi kalus memiliki morfologi yang sama. Kalus yang terbentuk berwarna putih kekuningan, transparan dengan struktur remah, kompak (Gambar 1b) dan lunak (Gambar 1c).

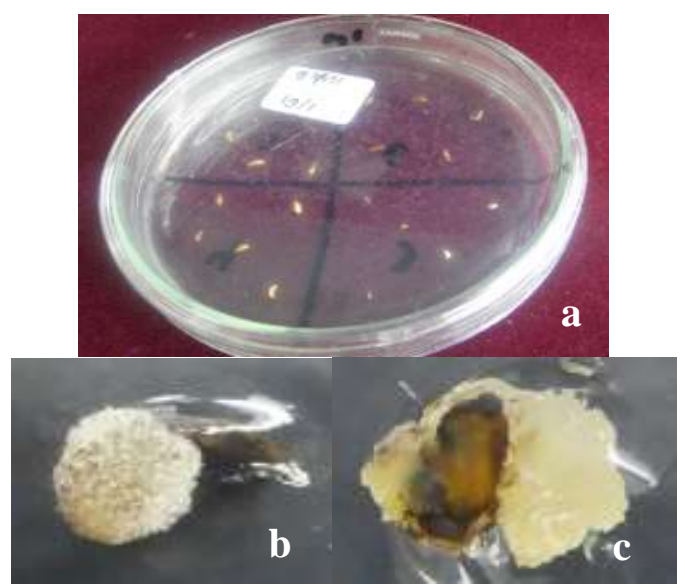

Gambar 1. Induksi pembentukan kalus. Inokulasi antera pada media induksi kalus (a), struktur kalus kompak, berwarna putih (b), struktur kalus lunak, transparan dan berwarna putih kekuningan (c) 
Hasil analisis ragam (Tabel 1) menunjukkan bahwa hanya media yang mempengaruhi lamanya inisiasi kalus sedangkan genotipe maupun interaksi keduanya tidak mempengaruhi lamanya inisiasi kalus. Hasil yang diperoleh menunjukkan bahwa kalus pertama terbentuk setelah kultur diinkubasi selama 26.4 hari (Tora) dan 27.7 hari (Ratna dan Permata) (Tabel 2). Tidak ada perbedaan yang nyata dalam inisiasi kalus antara media M1, M2,
M3, M4 dan M5. Kalus pertama terbentuk setelah kultur diinkubasi selama 25 hari, yaitu terjadi pada media M1 (DBMI $+5 \mathrm{mg} \mathrm{L}^{-1}$ kinetin $+2 \mathrm{mg} \mathrm{L}^{-1} \mathrm{NAA}$ ), dan kalus paling lama terbentuk selama 28 hari, yaitu pada media $\mathrm{M} 2$ (DBMI $+5 \mathrm{mg} \mathrm{L}^{-1}$ kinetin $+2 \mathrm{mg}$ $\mathrm{L}^{-1} \mathrm{NAA}$ ) (Tabel 3). Hal ini sejalan dengan penelitian Motallebi-Azar (2010) dan Asoliman et al. (2007) bahwa pembentukan kalus pada kultur antera tomat terjadi setelah 4 minggu atau 28 hari kultur.

Tabel 1. Hasil analisis ragam pengaruh genotipe dan media terhadap jumlah kalus, diameter kalus dan jumlah tanaman pada kultur antera tomat

\begin{tabular}{lcccc}
\hline \multirow{3}{*}{ Sumber Keragaman } & \multicolumn{3}{c}{ Percobaan 1 } & \multicolumn{3}{c}{ Percobaan 2 } \\
\cline { 2 - 5 } & \multicolumn{3}{c}{ Kuadrat Tengah } \\
\cline { 2 - 5 } & $\begin{array}{c}\text { Lamanya Inisiasi } \\
\text { Kalus }\end{array}$ & Jumlah Kalus & $\begin{array}{c}\text { Diameter } \\
\text { Kalus }\end{array}$ & Jumlah Tunas \\
\hline Genotipe & $39.80^{\text {tn }}$ & $3.99^{* * *}$ & $0.45^{\text {tn }}$ & $0.002^{\text {tn }}$ \\
Media & $27.79^{* *}$ & $6.69^{\text {t* }}$ & $0.03^{\text {tn }}$ & $0.0008^{\text {tn }}$ \\
Genotipe x Media & $39.92^{\text {tn }}$ & $0.61^{\text {tn }}$ & $0.10^{\text {tn }}$ & $0.0008^{\text {tn }}$ \\
KK & 17.08 & 17.94 & 23.56 & 7.12 \\
\hline
\end{tabular}

Keterangan: **= sangat nyata pada taraf $95 \%$, tn $=$ tidak nyata.

Tabel 2. Hasil uji DMRT perbedaan respon jumlah kalus serta nilai rata-rata Induksi kalus dan persentase jumlah kalus pada genotipe yang berbeda

\begin{tabular}{lccc}
\hline Genotipe & $\begin{array}{c}\text { Lamanya Inisiasi } \\
\text { Kalus (HST)* }\end{array}$ & Jumlah Kalus & $\begin{array}{c}\text { Persentase Jumlah } \\
\text { Kalus }(\%)^{*}\end{array}$ \\
\hline Tora & 26.4 & $2.8 \mathrm{~b}$ & 14.0 \\
Ratna & 27.7 & $2.4 \mathrm{~b}$ & 12.0 \\
Permata & 27.7 & $5.5 \mathrm{a}$ & 27.3 \\
\hline
\end{tabular}

Keterangan: *: Data tidak dianalisis statistik. Angka yang diikuti huruf yang berbeda pada kolom yang sama adalah berbeda nyata pada uji DMRT taraf $5 \%$.

Tabel 3. Hasil uji DMRT perbedaan respon jumlah kalus serta nilai rata-rata induksi kalus dan persen jumlah kalus pada media yang berbeda

\begin{tabular}{cccc}
\hline $\begin{array}{c}\text { Media Induksi } \\
\text { Kalus (M) }\end{array}$ & $\begin{array}{c}\text { Lamanya Inisiasi } \\
\text { Kalus (HST) }\end{array}$ & Jumlah Kalus & $\begin{array}{c}\text { Persentase Jumlah } \\
\text { Kalus }(\%)^{*}\end{array}$ \\
\hline M1 & $25.0 \mathrm{a}$ & $7.9 \mathrm{a}$ & 39.7 \\
M2 & $28.6 \mathrm{a}$ & $6.6 \mathrm{a}$ & 33.0 \\
M3 & $27.4 \mathrm{a}$ & $3.2 \mathrm{~b}$ & 16.0 \\
M4 & $26.4 \mathrm{a}$ & $1.8 \mathrm{bc}$ & 9.0 \\
M5 & $27.6 \mathrm{a}$ & $1.8 \mathrm{bc}$ & 9.0 \\
M6 & $0.0 \mathrm{~b}$ & $0.0 \mathrm{c}$ & 0.0 \\
\hline
\end{tabular}

Keterangan: *: Data tidak dianalisis. Angka yang diikuti huruf yang berbeda pada kolom yang sama adalah berbeda nyata pada uji DMRT taraf 5\%. 


\section{Jumlah Kalus}

Hasil yang diperoleh menunjukkan bahwa pembentukan kalus hanya terjadi pada satu bagian antera, yaitu pada daerah bagian pangkal antera, sehingga jumlah kalus sama dengan jumlah antera yang membentuk kalus. Hasil analisis ragam menunjukkan bahwa genotipe dan media secara tunggal mempengaruhi jumlah kalus yang dihasilkan, sedangkan interaksi keduanya tidak mempengaruhi jumlah kalus (Tabel 1). Hasil yang diperoleh menunjukkan bahwa jumlah kalus paling tinggi dihasilkan oleh genotipe Permata sebesar 5.5 berbeda nyata dengan genotipe Tora dan Ratna yaitu 2.8 dan 2.4, sedangkan jumlah kalus genotipe Tora dan Ratna tidak berbeda diantara keduanya (Tabel 2). Jumlah kalus yang dihasilkan oleh media $\mathrm{DBMI}+5 \mathrm{mg} \mathrm{L}^{-1}$ kinetin $+2 \mathrm{mg} \mathrm{L}^{-1} \mathrm{NAA}$ (M1) tidak berbeda nyata dengan DBMII + 1 mg L ${ }^{-1}$ kinetin $+2 \mathrm{mg} \mathrm{L}^{-1}$ NAA (M2) yaitu berturut-turut 7.9 dan 6.6, namun keduanya berbeda nyata dengan media lainnya. Perbedaan jumlah kalus antara genotipe tomat hasil kultur antera juga dilaporkan oleh Zamir et al. (1980) pada genotipe Person dan San Marzano, masing-masing 45 dan 22 kalus. Farooq et al. (2010) juga melaporkan perbedaan jumlah kalus yang dihasilkan dari genotipe Roma, Maya dan Rio Grande masing-masing 13, 20, dan 38 kalus.

\section{Efisiensi Pembentukan Kalus}

Efisiensi pembentukan kalus dari setiap genotipe yang dikulturkan pada enam media induksi kalus dinyatakan dengan persentase jumlah kalus terhadap jumlah antera. Hasil yang diperoleh menunjukkan bahwa genotipe Permata memiliki efisiensi pembentukan kalus paling tinggi yaitu sebesar $27 \%$, kemudian genotipe Tora $14 \%$ dan Ratna 12\% (Tabel 2). Efisiensi pembentukan kalus paling tinggi dihasilkan oleh media DBMI $+5 \mathrm{mg} \mathrm{L} \mathrm{L}^{-1}$ kinetin $+2 \mathrm{mg} \mathrm{L}^{-1} \mathrm{NAA}(\mathrm{M} 1)$ dan DBMII +1 $\mathrm{mg} \mathrm{L}^{-1}$ kinetin $+2 \mathrm{mg} \mathrm{L}^{-1}$ NAA (M2) berturutturut sebesar 39.7\% dan 33\% (Tabel 3). Media $\mathrm{DBMI}+5 \mathrm{mg} \mathrm{L}^{-1}$ kinetin $+2 \mathrm{mg} \mathrm{L}^{-1} \mathrm{NAA}$ juga dilaporkan menginduksi kalus secara optimal pada berbagai genotipe yang digunakan dalam penelitian-penelitian sebelumnya (Motallebi-Azar, 2010; Summers et al., 1992; Gresshoff dan Doy, 1972). Hasil ini menunjukkan bahwa media DBMI $+5 \mathrm{mg}$ $\mathrm{L}^{-1}$ kinetin $+2 \mathrm{mg} \mathrm{L}^{-1}$ NAA dapat digunakan secara luas untuk berbagai genotipe tomat.

Hasil yang diperoleh menunjukkan bahwa media M3 menginduksi kalus dengan efisiensi pembentukan kalus sebesar 16\%, lebih tinggi dibandingkan media M4, M5, dan M6 (Tabel 3), yang mana media M4, M5 dan M6 merupakan media yang berhasil menginduksi kalus dari kultur antera tomat pada penelitian sebelumnya (Motallebi-Azar, 2010; Zagorska et al., 1998). Beragamnya jumlah kalus dan efisiensi pembentukan kalus pada media yang digunakan menunjukkan bahwa genotipe yang berbeda mungkin saja membutuhkan media yang berbeda. Hal ini menyebabkan sulitnya memperoleh media yang universal untuk kultur antera tomat.

\section{Induksi Pembentukan Tunas Pertambahan Diameter Kalus}

Nilai pertambahan diameter kalus diperoleh dengan mengurangi besarnya diameter kalus minggu ke-6 dengan diameter kalus minggu ke-4. Hasil analisis ragam menunjukkan bahwa pertambahan diameter kalus selama 2 minggu yaitu, dari minggu ke- 4 hingga minggu ke-6 saat kultur tidak dipengaruhi oleh genotipe, media maupun interaksi keduanya. Baik media maupun genotipe yang digunakan menunjukkan besarnya pertambahan diameter kalus yang sama.

Hasil yang diperoleh menunjukkan bahwa pertambahan diameter kalus tomat Tora, Ratna dan Permata selama 2 minggu, yaitu sebesar 2.75, 1.40 dan $2.00 \mathrm{~mm}$. Pertambahan diameter kalus pada media MS + $1 \mathrm{mg} \mathrm{L}^{-1}$ zeatin $+0.125 \mathrm{mg} \mathrm{L}^{-1}$ IAA dan MS + $0.25 \mathrm{mg} \mathrm{L}^{-1}$ zeatin berturut-turut adalah 1.97 dan $2.13 \mathrm{~mm}$ (Tabel 4). Bertambahnya diameter kalus pada media induksi tunas dapat disebabkan oleh faktor genetik, yang mana genotipe yang digunakan memiliki daya regenerasi yang rendah, sehingga kalus terus berproliferasi tanpa adanya inisiasi tunas. Disamping itu, diduga keseimbangan konsentrasi dan jenis ZPT yang digunakan belum sesuai dengan genotipe yang digunakan sehingga belum mampu menginduksi munculnya tunas secara optimal. 
Tabel 4. Pertambahan diameter kalus, lamanya inisiasi tunas, jumlah tunas dan persen jumlah tunas terhadap jumlah kalus pada tiga genotipe tomat dan dua media regenerasi

\begin{tabular}{lcccc}
\hline Perlakuan & $\begin{array}{c}\text { Pertambahan } \\
\text { Diameter Kalus } \\
(\mathrm{mm})\end{array}$ & $\begin{array}{c}\text { Lamanya } \\
\text { Inisiasi Tunas } \\
\text { (HST) }\end{array}$ & $\begin{array}{c}\text { Jumlah } \\
\text { Tunas }\end{array}$ & $\begin{array}{c}\text { Persentase jumlah } \\
\text { Tunas Terhadap } \\
\text { Jumlah Kalus (\%) }\end{array}$ \\
\hline Genotipe & & & & \\
$\quad$ Tora & 2.75 & 57 & 0.19 & 2.1 \\
$\quad$ Ratna & 1.40 & 0 & 0.00 & 0.0 \\
$\quad$ Permata & 2.00 & 60 & 0.38 & 4.2 \\
\hline Media & & & & 1.4 \\
R1 & 1.97 & 68 & 0.01 & 2.8 \\
R2 & 2.13 & 58 & 0.25 & \\
\hline
\end{tabular}

\section{Lamanya Inisiasi Tunas}

Tunas pada genotipe Permata pertama kali muncul pada umur 60 hari dan 68 hari (Tabel 4). Masing-masing tunas muncul pada media MS + $0.25 \mathrm{mg} \mathrm{L}^{-1}$ Zeatin (R1) dan MS $+1 \mathrm{mg} \mathrm{L}^{-1}$ Zeatin $+0.125 \mathrm{mg} \mathrm{L}^{-1}$ IAA (R2). Tunas pada genotipe Tora pertama kali muncul pada umur 57 hari yaitu pada media R2. Bakal tunas kedua genotipe tumbuh cepat di hari-hari pertama pertumbuhan yaitu saat berumur 39 hingga 46 hari (Gambar 2a, b, c), kemudian pertumbuhan melambat yang diikuti dengan pencokelatan pada tunas setelah mencapai umur 91 hingga 138 hari (3-4 bulan) dikultur (Gambar 2d, e, f).

Bakal tunas yang muncul memiliki bentuk yang abnormal. Tangkai dan helaian daun genotipe Permata pada media R1 menunjukkan pertumbuhan memanjang dari permukaan kalus tanpa adanya batang. Daun tidak membuka sempurna namun terlihat jelas urat dan tulang daun, selain itu tidak ada inisisasi daun atau pun tunas baru selama inkubasi kultur (Gambar 2a). Bakal tunas yang abnormal juga ditunjukkan oleh genotipe Permata pada media R2. Daun terlihat kecil dan memanjang, runcing pada bagian ujung dengan tepi daun menggulung ke bagian dalam (Gambar 2b). Tunas yang abnormal juga dihasilkan oleh genotipe Tora pada media R2. Tunas terlihat transparan, dengan bentuk daun yang abnormal (Gambar 2c). Semua tunas yang terbentuk mengalami pencokelatan setelah 3 hingga 4 bulan dikultur (Gambar 2d, e, f). Pencokelatan pada tunas diawali pada bagian pangkal tunas, kemudian menyebar ke seluruh bagian tunas yang menandai akhir pertumbuhan tunas. Tunas yang terbentuk tidak dapat diregenerasikan pada media perakaran karena telah mengalami pencokelatan dan tunas yang terbentuk tunas yang abnormal.

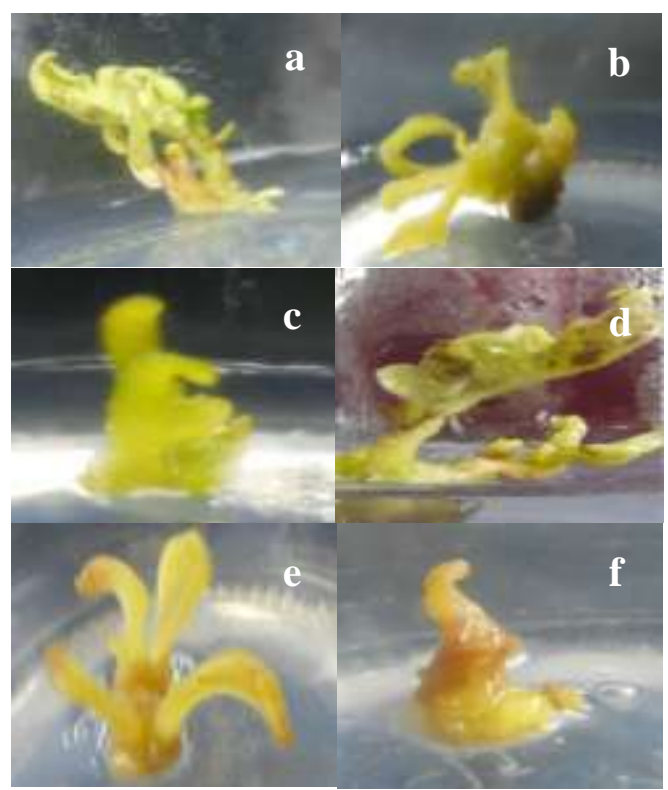

Gambar 2. Pertumbuhan tunas pada media R1 dan R2. Tunas tumbuh baik saat berumur 39 hingga 46 hari dikultur $(\mathrm{a}, \mathrm{b}, \mathrm{c})$. Tunas mengalami pencokelatan setelah berumur 91 hingga 138 hari (d, e, f)

\section{Jumlah Tunas}

Hasil analisis ragam menunjukkan bahwa banyaknya tunas yang terbentuk tidak dipengaruhi oleh genotipe maupun media yang digunakan (Tabel 1). Media maupun genotipe yang digunakan menunjukkan respon yang sama dalam menghasilkan tunas (Tabel 4). Genotipe Permata menghasilkan tunas paling banyak, yaitu 0.38 sedangkan genotipe Ratna tidak menghasilkan tunas sama sekali. Tunas hanya muncul sekali pada tiap kalus, dan tidak 
terjadi inisiasi tunas baru selama pertumbuhan tunas pertama. Media MS $+0.25 \mathrm{mg} \mathrm{L}^{-1}$ Zeatin dan MS + $1 \mathrm{mg} \mathrm{L}^{-1}$ Zeatin + $0.125 \mathrm{mg} \mathrm{L}^{-1}$ IAA menginduksi tunas berturut-turut sebanyak 0.25 dan 0.1 tunas.

Efisiensi pembentukan tunas paling tinggi hanya mencapai $4.2 \%$ yaitu dihasilkan oleh genotipe Permata. Efisiensi pembentukan tunas genotipe Tora dan Ratna lebih rendah yaitu berturut-turut $2.1 \%$ dan $0 \%$. Efisiensi pembentukan tunas paling tinggi dihasilkan oleh media $\mathrm{MS}+0.25 \mathrm{mg} \mathrm{L^{-1 }}$ Zeatin yaitu sebesar $2.8 \%$, sedangkan media $\mathrm{MS}+1 \mathrm{mg} \mathrm{L}^{-1}$ Zeatin $+0.125 \mathrm{mg} \mathrm{L}^{-1}$ IAA menghasilkan efisiensi pembentukan kalus $1.4 \%$ (Tabel 4). Hasil penelitian terdahulu menggunakan media $\mathrm{MS}+1 \mathrm{mg} \mathrm{L}^{-1}$ Zeatin + $0.125 \mathrm{mg} \mathrm{L}^{-1}$ IAA dan $\mathrm{MS}+0.25 \mathrm{mg} \mathrm{L}^{-1}$ Zeatin mampu menghasilkan tanaman hingga aklimatisasi (Motallebi-Azar, 2010; Zagorska et al., 1998). Hal ini menunjukkan bahwa genotipe sangat menentukan keberhasilan kultur antera tomat (Motallebi-Azar, 2010; Shtereva et al., 1998; Zagorska et al., 1998).

\section{KESIMPULAN}

Tomat Permata memiliki respon kultur antera yang lebih baik dibandingkan genotipe Tora dan Ratna dalam jumlah kalus maupun jumlah tunas. Media yang paling baik menginduksi kalus adalah media M1 (DBMI + $5 \mathrm{mg} \mathrm{L}^{-1}$ kinetin $\left.+2 \mathrm{mg} \mathrm{L}^{-1} \mathrm{NAA}\right)(39 \%)$ dan $\mathrm{M} 2\left(\mathrm{DBMI}+1 \mathrm{mg} \mathrm{L}^{-1}\right.$ kinetin $+2 \mathrm{mg} \mathrm{L}^{-1}$ NAA) (33\%). Media yang paling baik menginduksi tunas adalah media R2 (MS + $0.25 \mathrm{mg} \mathrm{L}^{-1}$ zeatin) $(2.8 \%)$.

\section{DAFTAR PUSTAKA}

Asoliman, S.S., T.A. Ismail, M.A. Zaki, E.S. Amer. 2007. Genetic studies on tomato anther culture. Factors affecting induction of androgenesis in tomato anther culture. Afr. Crop Sci. 8: 759768 .

[BPS] Badan Pusat Statistik. 2013. Produksi Sayuran di Indonesia Tahun 1997-2013. http://www.bps.go.id. [4 September 2014].
Dewi, I.S., B.S. Purwoko. 2011. Kultur in vitro untuk produksi tanaman haploid androgenik. Halaman 107-142. In G.A. Wattimena, A.M. Nurhajati, N.M.A. Wiendi, A. Purwito, D. Efendi, B.S. Purwoko, N. Khumaida. Bioteknologi dalam Pemuliaan Tanaman. Bogor. IPB Press.

Dewi, I.S., B.S. Purwoko. 2001. Kultur antera untuk mendukung program pemuliaan tanaman padi. Bul. Agron. 29: 59-63.

Dewi, I.S., B.S. Purwoko, H. Aswidinnoor, I.H. Somantri, M.A. Chozin. 2009. Plant regeneration from anther cultures of several genotypes of indica rice tolerant to alumunium toxicity. Indonesian J. Agric. 2(1): 1-5.

Dewi, I.S., B.S. Purwoko, H. Aswidinnoor, I.H. Somantri. 2007. Regenerasi tanaman pada kultur antera padi: pengaruh persilangan dan aplikasi putresin. Bul. Agron. 35(2): 68-74.

Direktorat Jenderal Hortikultura. 2011. Rencana Strategis Direktorat Jenderal Hortikultura Tahun 2011-2014. http:// www.pertanian.go.id/sakip/admin/file/R ENSTRAHOR.pdf. [21 Januari 2015].

[FAO] Food and Agricultural Organization. 2015. Food and Agricultural Commodities Production/Commodities by Regions. faostat3.fao.org. [04 Maret 2015].

Farooq, A.M., B. Tabassum, I.A. Nasir, T. Husnain. 2010. Androgenesis induction, callogenesis, regeneration and cytogenetic studies of tomato haploid. J. Agric. Res. 48(4): 457-470.

Gresshoff, P.M., C.H. Doy. 1972. Development and differentiation of haploid Lycopersicon esculentum (tomato). Planta. 107: 161-170.

Harliani, E.N., E.R. Palupi, D.S. Wahyudin. 2014. Potensi penyimpanan serbuk sari dalam produksi benih hibrida mentimun (Cucumis sativus L) varietas KE014. J. Hort. Indonesia. 5(2): 104-117. 
Kartikaningrum, S., A. Purwito, G.A. Wattimena, B. Marwoto, D. Sukma. 2012. Induksi tanaman haploid Dhiantus sp. melalui pseudofertilisasi menggunakan polen yang diiradiasi dengan sinar gamma. J. Hort. Indonesia. 4(1): 16-25.

Motallebi-Azar, A. 2010. Androgenic response of tomato (Lycopersicon esculentum Mill.) lines and their hybrids to anther culture. Russian Agric. Sci. 4: 250-258.

Motallebi-Azar, A., J. Panahandeh. 2010. Effects of colchicine and cold duration pretreatments on androgenesis responses of tomato (Lycopersicon esculentum Mill.) via anther culture. Russian Agric. Sci. 5: 338-341.

Safitri, H., B.S. Purwoko, D.Wirnas, I.S. Dewi, B. Abdullah. 2010. Daya kultur antera beberapa persilangan padi gogo dan padi tipe baru. J. Agron. Indonesia. 38(2): 81-87.

Seguì-Simarro, J.M., F. Nuez. 2007. Embryogenesis induction, caullogenesis and plant regeneration by in vitro culture of tomato isolated microspores and whole anthers. J. Exp. Botany. 58: 1119-1132.

Seguì-Simarro, J.M., F. Nuez. 2005. Meiotic metaphase I to telophase II as the most responsive stage during microspore development for callus induction in tomato (Solanum licopersicum) anther cultures. Acta Physiol. Plantarum. 27: 675-685.
Sudarmono, Destri. 2013. Fungsi tuas stamen dalam penyerbukan dan potensi bunga Salvia sebagai tanaman hias di kebun raya Cibodas. J. Hort. Indonesia. 4(2): 94-97.

Shtereva, L.A., N.A. Zagorska. B.D. Dimitrov. M.M. Kruleva, H.K. Oanh. 1998. Induced androgenesis in tomato (Lycopersicon esculentum Mill). II. Factors affecting induction of androgenesis. Plant Cell Reports. 18: 312-317.

Sharp, W.R., R.S. Raskin, H.E, Sommer. 1972. The use of nurse culture in the development of haploid clones in tomato. Planta (Berl). 104: 357-361.

Summers, W.L., J. Jaramillo, T. Bailey. 1992 Microspore developmental stage and anther lenght influence the induction of tomato anther callus. HortScience. 27(7): 838-840.

Syukur, M., S. Sujiprihati, R. Yunianti. 2012. Teknik Pemuliaan Tanaman. Penebar Swadaya, Jakarta.

Zagorska, N.A., A. Shtereva, D. Dimitrov, M.M. Kruleva. 1998. Induced androgenesis in tomato (Lycopersicon esculentum Mill.) I. Influence of genotype on androgenetic ability. Plant Cell Reports. 17: 968-973.

Zamir, D., R.A. Jones, M. Kedar. 1980. Anther culture of male-sterile tomato (Lycipersicon esculentum Mill.) mutants. Plant Sci. Letters. 17: 353-361. 